\title{
The Opportunity of Recycling Waste Ceramics in Daily Necessities Design Based on Ecological Civilization Construction*
}

\author{
Quanheng Li \\ Guangdong Industry Polytechnic \\ Guangzhou, China
}

\begin{abstract}
The construction of ecological civilization is an important part of the overall layout of the "five in one" and the four-pronged comprehensive strategy. At present, based on the transition from industrialization to a low-carbon economy, strengthening awareness of the whole people's environmental protection, and promoting the trend of green development, the paper explores and analyzes the opportunity of recycling waste ceramics in daily necessities design from the four aspects of advantages, disadvantages, opportunities, and threats. In the analysis, the new start, new business opportunities, and new opportunities are clearly seen. It is clear that under the current trend of green development, the application of recycling waste ceramic in daily necessities design is feasible.
\end{abstract}

Keywords-ecological civilization construction; waste ceramic; recycle; daily necessities; opportunities

\section{INTRODUCTION}

In November 2012, the18th National Congress of the Communist Party of China set out from a new historical starting point, making a strategic decision to "vigorously promote ecological progress," and drawing a grand blueprint for the construction of ecological civilization from ten aspects. In October 2015, with the convening of the Fifth Plenary Session of the 18th CPC Central Committee, strengthening the construction of ecological civilization was first written into the national five-year plan. On the afternoon of May 26, 2017, the Political Bureau of the Central Committee of the Communist Party of China carried out the forty-first group study on promoting the formation of green development modes and lifestyles. When presiding over the study, Xi Jinping, General Secretary of the Communist Party of China, stressed that promoting the formation of green development modes and lifestyles is an inevitable requirement for implementing the new development concept. We should place ecological civilization construction in a prominent position in the overall work, and adhered to the basic national policies of saving resources and protecting the environment. We should adhere to the principle of saving at first, protection at first, and attach most importance to natural recovery, form spatial patterns, industrial structure, production methods, lifestyle of saving resources and

*Fund: Project for Training Outstanding Young Teachers in Colleges and Universities in Guangdong Province (YQ2015173). protecting the environment, and strive to achieve common development of economic and social development as well as ecological environment protection to create a good production and living environment for the public. In the forty-first group study, it was proposed that promoting to form green development methods and lifestyles to create a good production and living environment for the people. General Secretary Xi Jinping proposed six key tasks for promoting the formation of green development methods and lifestyles: First, speeding up the transformation of economic development methods; Second, increasing the comprehensive treatment of environmental pollution; Third, accelerating the restoration of ecological protection; Fourth, comprehensively promoting resource saving and intensive utilization; Fifth, advocating the promotion of green consumption; Sixth, improving the system of ecological civilization. The collective study brings people an opportunity to improve the ecological environment; a new starting point for industrial development models; and opportunities for the transformation of recycling waste ceramic into daily necessities.

\section{The RANGe OF DAILY Design fOR WASte CERAMIC RECYCLING}

Large-scale industrial production of ceramics also produced a large number of waste ceramics. The waste ceramics have been fired at high temperatures and are difficult to be degraded under natural conditions, which pose significant environmental pollution. If these abandoned ceramics are reused, they will promote the environment and green development greatly. Discarded ceramics are common but inconspicuous. They are simple and practical. The daily necessities are quite wide. We are here mainly to talk about some commonly used industrial products in daily life and work. Abandoned ceramics can create not just artwork but functional daily industrial products that meet the needs of consumers. At the same time, they can design daily industrial products that lead consumer demand to bring personalized, comfortable, practical, healthy and beautiful products for consumers by creating daily-use industrial products. The feasibility of discarded ceramics in the design of daily necessities can be divided into the following categories (seeing Table I). 
TABLE I.

Feasible Design of Waste Ceramics in Daily NECESSITIES

\begin{tabular}{|c|c|c|}
\hline No. & category & Major Coverage \\
\hline 01 & $\begin{array}{l}\text { Electronic } \\
\text { daily } \\
\text { necessities }\end{array}$ & $\begin{array}{c}\text { Players, timers, cameras, digital concepts, and } \\
\text { other daily necessities }\end{array}$ \\
\hline 02 & $\begin{array}{l}\text { Tableware } \\
\text { daily } \\
\text { necessities }\end{array}$ & $\begin{array}{l}\text { Cup containers, tableware, chopsticks, knives } \\
\text { and forks, food containers, dessert racks, fruit } \\
\text { bowls, coasters, wine accessories, etc. }\end{array}$ \\
\hline 03 & $\begin{array}{l}\text { Bathroom } \\
\text { daily } \\
\text { necessities }\end{array}$ & $\begin{array}{l}\text { Towel racks, toothbrush holders, stoppers, } \\
\text { clothes hooks and other daily necessities }\end{array}$ \\
\hline 04 & $\begin{array}{l}\text { Lighting } \\
\text { daily } \\
\text { necessities }\end{array}$ & $\begin{array}{l}\text { Decorative floor lamps, table lamps, holiday } \\
\text { lamps, ceiling lamp, atmosphere lamps and } \\
\text { other daily necessities }\end{array}$ \\
\hline 05 & $\begin{array}{l}\text { Clothing and } \\
\text { daily } \\
\text { necessities }\end{array}$ & $\begin{array}{c}\text { Jewelry, jewelry boxes, fashion goods and } \\
\text { other daily necessities }\end{array}$ \\
\hline 06 & $\begin{array}{l}\text { Ceroplastic } \\
\text { Daily } \\
\text { Necessities }\end{array}$ & $\begin{array}{l}\text { Candlesticks, candle holders, candle holders } \\
\text { and other daily necessities }\end{array}$ \\
\hline 07 & $\begin{array}{l}\text { Decoration } \\
\text { daily } \\
\text { necessities }\end{array}$ & $\begin{array}{c}\text { Flower implement, tea sets, photo frames, } \\
\text { creative clocks, aquariums, fragrant utensils, } \\
\text { hanging crafts, small sculptures, small } \\
\text { furniture and other daily necessities }\end{array}$ \\
\hline 08 & $\begin{array}{l}\text { Daily } \\
\text { necessities in } \\
\text { study }\end{array}$ & $\begin{array}{l}\text { Four Treasures of the Study and other daily } \\
\text { necessities }\end{array}$ \\
\hline
\end{tabular}

In general, the design of waste ceramics in the daily necessities positioning mainly involves the daily necessities of our daily life. In this range, there is no difference in sizes, but it emphasizes on the use of packtech in the recycle of ceramic waste materials as well as design creativity. The key point of it is skillfully and appropriately using waste ceramics in daily necessities, cultural and creative products, artwork design to reflect the design concept of recycling, save resources, protect the environment and promote green development.

\section{OPPORTUNITIES ANALYSIS FOR TRANSFORMING WASTE CERAMICS INTO DAILY NECESSITIES}

The construction of ecological civilization is a long-term plan for the well-being of the people and national future. The Party Central Committee and the State Council of the People's Republic of China attach great importance to the construction of ecological civilization. They have successively issued a series of major decision-making arrangements and have made significant progress and positive achievements in promoting the construction of ecological civilization. This is a very good time. The application of abandon ceramic recycling in the design of daily necessities provides new design and creative ideas for daily necessities design, which helps the innovation of daily necessities design open up a favorable market position. Through the SWOT analytical method, the opportunity analysis of the waste ceramic reuse in the daily product design is carried out, from which the favorable and worthwhile-developed factors, as well as the unfavorable factors and the factors that need to be avoided are organically integrated. It provides favorable information for the formulation of strategic measures for the transformation of waste ceramics into daily necessities, develops effective strategies, and promotes green development.

\section{A. Advantage Analysis}

First of all, it is a policy advantage. China has introduced a lot of policies to give a lot of support for waste recycling, reuse, and recycling of resources. The state has successively promulgated laws and regulations such as "Law on Energy Saving of The People's Republic of China", and "Circulation Economy Promotion Law of The People's Republic of China", it also introduced standardize industrial policies such as "regulations on renewable resources recovery," and "Outline of policy on Comprehensive Utilization of Technical Resources in China". At the same time, in recent years, people have been more concerned with the concepts of green design and environmental protection, which play the role of promotion on education. In addition, the government has begun to vigorously rectify environmental pollution. By the end of last year, Beijing, eight provinces (or municipalities) including Tianjin, Jiangsu, Zhejiang, Anhui, Fujian, Jiangxi, and Hainan had issued documents that implementing river chief system in the whole province (or municipality), and the river chief system has been implemented in some cities, counties or watershed systems in 16 provinces (autonomous regions and municipalities directly under the Central Government) such as Shanxi and Liaoning. Comprehensive inspections and environmental protection interviews have encouraged local governments to strengthen environmental governance, and to improve environmental quality through implementing individualized policies in different areas and acting appropriately to the situation. In the forty-first group study at the Political Bureau of the CPC Central Committee, General Secretary Xi Jinping emphasized again that promoting the formation of green development methods and lifestyles was an inevitable requirement for the implementation of new development concepts. Ecological civilization construction must be placed in a prominent position in the overall work, and the basic state policy of saving resources and protecting the environment should be adhered to. We should adhere to the principle of saving at first, protection at first, and attach most importance to natural recovery, form spatial patterns, industrial structure, production methods, lifestyle of saving resources and protecting the environment, and strive to achieve common development of economic and social development as well as ecological environment protection to create a good production and living environment for the public. At present, these national policies and practical actions will bring new channels for the reuse of discarded 
resources, and will also give waste ceramics opportunities on the application in daily necessities design.

Second, it is an advantage in Science and technology. With the rapid development of economy and the large-scale development of industrialization, people's waste resources recycling and organic integration of waste resource have become the research topics of universities, thinking of enterprise technology research, and the focuses of the whole society. These current conditions have also promoted further research on the reuse of abandoned resources by people from all walks of life, transformed a series of studies into achievements and promoted the coordinated development of science and technology, economy, and society. These science and technology are also effective in helping waste resources recycling in a very reasonable way, saving development resources, optimizing industrial structure, and eliminating outdated production capacity and technologies that endanger human health as well as controlling the environmental governance from the source. It has also become a great help in the application of waste ceramic recycling in daily necessities design, and there have been some successful cases of waste ceramics recycling design in China.

\section{B. Disadvantage Analysis}

First, large-scale industrial production produces large quantities of waste products and the global environment is deteriorating. With the rapid development of economy in China, the large-scale development of bubble real estate and industrial flow production have generated a large number of wastes. It has become a social consensus that the production caused the destruction of ecological environment. Waste materials such as industrial excess stock, leftover bits and pieces, and used component materials are the main sources of environmental pollution, and waste ceramics are one of them. The waste ceramics themselves are already the products after high temperature firing, and their plasticity needs to be improved. Even if crushing cannot solve the problem, for the manufacturing process of smashing and reshaping the ceramics is immature because of firmness of the ceramics and the glaze color of the surface. All of these put forward high requirements and difficulties for the transformation of waste ceramics into daily commodities.

Second, there is a lack of systematic integration and reasonable planning. Waste resource materials are a large amount of renewable resource materials, and the system integration and reasonable planning and utilization give a new way of recycling waste resources. However, there are few companies that recycle, classify and reuse waste resources in China, and companies with the orientation of waste ceramics recycling are fewer and fewer. A national recycling economy industrial chain should be established to systematically integrate and plan production-oriented enterprises, recycling waste industry, recycling research institutions, waste recycling enterprises, and related industries. Such an industrial chain can treat waste resources more rationally and resourcefully and improve the rational utilization of waste resources. At present, it has not been a large-scale industrial chain, but there are already some companies that are beginning to operate in this direction, which is a good sign. It also promotes the organic integration and reasonable planning of waste resource systems and is moving towards green development.

\section{Opportunity Analysis}

First, the whole world moving to a low-carbon economy will promote the formation of green development. Under this trend, the global economy is shifting towards a low-carbon economy. This is a pressure and an opportunity. Avoiding excessive dependence on the development path of high energy and high consumption taken by the developed countries, China's development of a low-carbon economy turns to an ecological, low-carbon industrial structure and takes a new industrial road of low-emission and lowconsumption, which will become the future dominant trend of social and economic development in China. It also promotes an important strategic choice for the transformation of waste ceramics into daily commodities.

Second, consumers' consumption ideas change. As the concept of sustainable development such as green design, eco-design, and waste recycling has been paid much attention, people have become more aware of ecoenvironment protection, consumers have attached great importance to low-carbon and environmentally-friendly products, and especially the young generation are paying more attention to the concept of sustainable development. In addition, in recent years, there have been trends in the international design trend of waste resources recycling and universalization of low-carbon life, promoting the formation of green development methods and lifestyles. Therefore, under the changing of consumption concept of consumers and in the environment of waste resources recycling as well as under the trend of promoting green development, there will be a place for the application of waste ceramic recycling in the design of daily necessities.

Third, internationally available technologies carry out mutual transfer and cooperation. At the Copenhagen conference, there was good news about the development of China's low-carbon economy, so the Western countries were willing to make commitments for transferring low-carbon technologies to developing countries such as China. At the recent "Belt and Road" international cooperation summit forum, the "One Belt and One Road" international production capacity cooperation, jointly developing thirdparty markets, technology transfer, and joint venture cooperation were solidly promoted. In addition, many years of research in this area of China have obtained some achievements and continuous improvement in science and technology. All of these have given China a good opportunity to study low-carbon technologies and develop low-carbon economy. Relying on the power of international cooperation and domestic technology with the addition of a sound scientific research system of waste recycling, it is very favorable for the application development of waste ceramics recycling in daily necessities. 


\section{Threat Analysis}

First of all, the process transformation technology of waste ceramic recycling is not mature and the level of existing research is not deep enough. In the technology of recycling waste resources, it cannot be said that it can be fully utilized. However, the technology of waste ceramics recycling is a challenge for us. As a fired waste ceramic material, its use in daily-use products require an understanding of the material including culture, characteristics and so on, and it also retains the waste traces and cultural symbols of waste ceramics, so there is a certain degree of difficulty with techniques. The technology, which is only used for recycling waste ceramic materials, is immature, which will result in investment risks such as high operating costs and limited application scope. Therefore, the transformation of waste ceramics into daily necessities will be affected, but the overall threat is small.

Second, industry-specific standards have not been introduced. The recycling of discarded resources requires large-scale, orderly development, and it also requires industry-specific standards work as guidelines and specifications. However, at present, there is no systematic and uniform industry standard for the recycling of discarded resources in China, which is also a big challenge to the application of waste ceramic recycling in daily necessities, and it also affects the transformation of discarded ceramics into daily necessities. Although there has been some recycling of waste in recent years, however, most of them are random, accidental or blind, lacking specific standards of the industry to guide and regulate.

\section{E. General Analysis}

Based on the opportunity of recycling waste ceramics for promoting green development in the design of daily necessities, the following conclusions have been obtained according to advantages analysis, disadvantage analysis, opportunity analysis and threat analysis through the comprehensive analysis of SWOT (seeing Table II).

From the above data, it can be seen that the reuse of waste ceramics in daily product design is a good opportunity. Through SWOT comprehensive analysis, although there are some disadvantages and threats, it is clear that advantages and opportunities are more than disadvantages and threats. In our late design, we will make full use of policy support, accelerate basic innovation, combine domestic and foreign technologies and cooperation, and pay attention to and avoid disadvantages and threats. We will use its strengths and opportunities and create competitive advantage as the core strategy to make better application of waste ceramics in daily necessities design so as to promote green development.
TABLE II. SWOT ANALYSIS TABLE

\begin{tabular}{|c|c|}
\hline Advantage & Inferiority \\
\hline $\begin{array}{l}\text { National Support Policy ("Five } \\
\text { in One", "Four-Pronged } \\
\text { Comprehensive Strategy" and } \\
\text { other related policies). } \\
\text { Global Development Trend of } \\
\text { Green and environmental } \\
\text { protection. } \\
\text { The people's environmental } \\
\text { awareness. } \\
\text { Having a certain amount of } \\
\text { scientific technology and } \\
\text { research results. }\end{array}$ & $\begin{array}{l}\text { It takes time for people to accept } \\
\text { such products. } \\
\text { The production process is not } \\
\text { mature enough. } \\
\text { Lack of systematic integration } \\
\text { and reasonable planning. }\end{array}$ \\
\hline Opportunity & Threat \\
\hline $\begin{array}{c}\text { Transferring to a low-carbon } \\
\text { economy and promoting the } \\
\text { development of green } \\
\text { development. } \\
\text { Similar commodities leading } \\
\text { consumers to pursue } \\
\text { personalized products. } \\
\text { Depending on designers } \\
\text { developing products. } \\
\text { International Technology } \\
\text { Transfer, "One Belt One Road" } \\
\text { International Capacity } \\
\text { Cooperation. }\end{array}$ & $\begin{array}{l}\text { Immature technology of fired } \\
\text { waste ceramic recycling. } \\
\text { Without specific standards of } \\
\text { the industry. }\end{array}$ \\
\hline
\end{tabular}

\section{The Sustainability OF WASTE CERAMICS TRANSFORMING INTO DAILY NECESSITIES}

The sustainable development is our biggest demand now, and it is also one of the methods to solve the shortage of social energy and resources, especially the sustainable transformation of abandoned resources. Waste ceramics have a certain degree of creativity, and the sustainable conversion of these waste ceramics will bring new ways for the recycling of renewable resources. It will also add value to waste materials such as waste ceramics. The colorful discarded ceramics with the state of the whole, half, onefourth, and even crushed granules, reunited to form a super artistic picture. It is not necessary to destroy the old and produce new ones, and the collision between tradition and fashion can also produce the innovative beauty of materials.

First, conceiving sustainable conversions from the experiment of material all in one piece. The various production processes and final effects of the whole waste ceramic will be compared with each other to continue the sustainable conversion of ideal design effects. There may be some chance or arbitrariness in the process, and it is not important. We should find a solution to transform the effect 
of contingency continuously as planned. We should make full use of the advantages of the whole area to recombine and arrange in an orderly manner to construct the overall visual effect of waste ceramics. Next, conducting waste materials experiments. Fragments are irregular, which causes the fragments to be mottled and scattered, producing a unique effect. In the design practice, it is possible to combine the front face and the transection of the waste ceramic fragments, and it is possible to consciously carry out the planned reservation of the cracks of the fragments in the process of the transformation. Third, reusing crushed granules to improve their plasticity, enrich their changes, and create unique daily necessities. Recycling of waste ceramics to sustainable development began with adding value to conceiving sustainable conversion. Fired waste ceramics are waste materials that make people feel worthless. Designers transform waste materials sustainably and promote green development by continuing the life cycle of them through their creativity, or creating new life for waste materials and creating new values for waste ceramics (seeing Table III).

TABLE III. INDICATOR SYSTEM FOR SUSTAINABLE CONVERSION OF WASTE CERAMICS

\begin{tabular}{|c|c|c|}
\hline $\begin{array}{c}\text { Input } \\
\text { indicators }\end{array}$ & Process indicators & Output indicators \\
\hline Human input & $\begin{array}{c}\text { Innovative design, } \\
\text { recycling, low carbon } \\
\text { development }\end{array}$ & $\begin{array}{c}\text { Conversion of the } \\
\text { whole Waste material }\end{array}$ \\
\hline $\begin{array}{c}\text { Technology } \\
\text { input }\end{array}$ & $\begin{array}{c}\text { Upcycling and saving } \\
\text { resources }\end{array}$ & $\begin{array}{c}\text { Conversion of waste } \\
\text { scraps }\end{array}$ \\
\hline $\begin{array}{c}\text { Technology } \\
\text { improvement } \\
\text { investment }\end{array}$ & $\begin{array}{c}\text { Production method and } \\
\text { life style of protecting } \\
\text { the environment }\end{array}$ & $\begin{array}{c}\text { Commercial Output } \\
\text { (Improvement of } \\
\text { Added Value) }\end{array}$ \\
\hline
\end{tabular}

\section{CONCLUSION}

In fact, the construction of ecological civilization is to upgrade sustainable development to the level of green development, that is to say "planting trees" for future generations to "cool down", which means leaving more ecological assets but regrets for the futurity. Today, green development is promoted. The application of waste ceramic recycling in the daily necessities design is a design concept of resource recycling, a green design concept, and a positive design concept. Compared with other design concepts, it started late, and even in the initial stage, but the trend is inevitable. It is in line with the development needs of the modern market and the needs of a sustainable development society. In the future of daily necessities design, it can speed up the upgrading of daily necessities design, promote social and economic development, improve the living environment, promote human and ecological balance, and has broad prospects for development and a new direction of development. We should make waste resources recycling widely used in the ecological design concept of daily necessities, and gradually enjoy popular support as well as make deeper research and innovation to reflect the connotation of daily necessities design such as energy saving, environmental protection, true ecology health and having cultural tastes.

In general, we should adhere to the basic state policy of saving resources and protecting the environment. In daily necessities design, making waste ceramics recycling focus on promoting green development, recycling development, and low-carbon development to form a spatial structure and industrial structure that conserves resources and protects the environment, production methods and lifestyles is a feasible and rare opportunity, a new starting point, a favorable condition in competition, and a new opportunity as well. Reversing the trend of ecological environment deterioration from the source creates a favorable production and living environment for the people, and makes contributions to global ecological security.

\section{REFERENCES}

[1] Quanheng Li. 《Analysis on the Sustainability of Home Supplies Design》 [M]. ICASSEE 2017, ISBN(on-line):978-94-6252-438-5, 2017, 11: 277-279.

[2] He Keding. The Revival of Traditional Handicraft Ceramics in Jingdezhen under the New Economic Situation [J]. Chinese Ceramics, 2015, 11: 88-91. 何科丁. 新经济形势下景德镇传统手工艺陶瓷的复 兴[J].中国陶瓷，2015，11：88-91.

[3] Yang Xiaoling, Han Wenya. Green life promotes green development [J]. Environmental Protection Science, 2015, 05:22-25.杨小玲, 韩文 亚.绿色生活推动绿色发展 [J].环境保护科学, 2015，05: 22-25.

[4] Li Quanheng. Innovative Design of "Reuse of Waste" in Home furnishings Design [J]. Design, 2014, 07: 190-191. 李全恒.家居饰用 品设计中“废弃物再利用”创新设计[J].设计，2014，07：190-191.

[5] Liu Ming. Analysis of the current status of Guangcai in the traditional craft industry [J]. Modern Decoration (Theory), 2015, 06:156. 刘明.关 于广彩在传统工艺产业的现状分析 [J]. 现代装饰（理论）, 2015, 06: 156 .

[6] Jia Mengdi, Ma Yun. Discussion on Application of Individualized Design in Daily Necessities Design [J]. Art Science and Technology, 2013, 08: 195-196. 贾梦迪，马云.浅谈个性化设计在日常用品设计 中的应用[J].艺术科技, 2013，08: 195-196. 